\title{
Rules of Three Analysis in Persuasive Public Speaking Presentation
}

\author{
Yuli Angraini \\ English Education Department \\ University of Riau Kepulauan \\ angraini_yuli@yahoo.com
}

\begin{abstract}
The objectives of this study were (1) to describe the effect of rules of three on persuasive public speaking presentation in speaking class and (2) to identify kinds of rules of three used by students in speaking class. The method of the study was descriptive study. Population of the study was all fourth semester students of Faculty of Teacher Training and Education in English Department in UNRIKA Kepulauan Riau Batam in Academic Year 2015/2016. The sample of this study was 24 students of fourth semester of Faculty of Teacher Training and Education in English Department in UNRIKA Kepulauan Riau Batam in Academic Year 2015/2016. The data was collected by using CD-RW form of presentation submitted by students. The data was analyzed and described by using Speech Evaluation Form which consisted of delivery of the speech and structure of the speech. It was identifiedthat only one group used rules of three in their group's persuasive public speaking presentation and it made their speech more focus and understandable while other three groups ignored the rules of three in their persuasive public speaking presentation and it led to the message of the speech went nowhere as the audience caught many aspects inside it too broad. If rules of three used in persuasive public speaking, then it will bring them to success and possible for any of them who wants to be the next top-paid public speaker if they know how to use that technique during their speech ratherin the future.
\end{abstract}

Keywords: rules of three, persuasive, public speaking presentation

\section{INTRODUCTION}

There was time when people being asked to speak in front of the public whether in a wedding ceremony, birthday party, or in the office. It would be easy for some of them, if they already knew before the event. They could prepare anything from writing notes, do some observation on what kinds of event they would face, or who would be their audience, what situation they would meet. They could even take slides of their presentation and pour their ideas into actions while talking to their audiences. From interview part, they could try to get to know their audiences by talking to them or to people who already invited them by asked 
some information so they would get such a raw description that they could develop later. By doing so, they will surely be a center of the event and not impossible for them being noticed by the guests or audiences that this is it-kinds of people they want to invite in their event. The more famous and popular them, the more money they will get as the most wanted public speaker. However, it needs process as things cannot happen automatically. Through the right practice, any people can be a high quality of public speaker. However, if facing the moment that no need practice because they are asked as a public speaker suddenly, then it means all they need just one, that is self-confidence. Without that, no matter how great they are, if they too much pay attention to the acceptance of their audiences, for example, when they make a joke in their speech for the sake of breaking the ice but not work at all, they will be much more frustrated if they repeat their joke and say sorry to their audience. In that case, they already lost their charm and value. No one will invite them again which for some people would be total failure. The worst thing is they will no longer choose a public speaker as their job as they think that their failure as the end of the world. To avoid that, people need to know the purpose of their speech before they talk in public, whether to inform, to entertain or to persuade. The most common one is persuasive public speaking. Persuasive public speaking is the type of public speaking that focuses on persuading people. This event can be seen everywhere. In the game where the coach did speech towards his or her team that lost the point in the game. Through his or her speech can have two effects. First if his or her speech cannot trigger his or her team's motivation then the next game result can be predicted.

Second, if he or she choose the right words to his or her team that can burn their spirit into fire then it works. The same things will have similar effects if the sellers or advertisers try to promote their product to their customers. To attract their customers or buyers, they need to find the great suitable words as their opening as usually customers or buyers have limited time to hear them. If they have no marvelous short words to point why their customers or buyers should listen or buy then they already lose their chance to sell it. In other words, no income for them that day.

Rules of three are one of the technique in public speaking. It is used to emphasize the point of the speech to the audiences in memorable ways. The speakers who use this technique can focus more while they deliver their speech. It can also reduce their stage-freak. Gallo (2014) said that The rule of three simply means that people can remember three pieces of information really well in short-term memory; add more items and retention falls off considerably. As more and more items are added to a list, the average person retains less and less. Four items are a bit harder to remember than three. Five items are even harder. Once the 
number of items on a list hits eight, most people have little chance of remembering the entire sequence. In brief, it is very useful for public speaker to apply this technique when they want to speak in public. The importance of rules of three in persuasive public speaking made the writer wanted to to analyze the effect of rules of three on persuasive public speaking presentation in speaking class and to identify kinds of rules of three used by students in speaking class through descriptive research entitled, "RULES OF THREE ANALYSIS IN PERSUASIVE PUBLIC SPEAKING PRESENTATION."

\section{CONCEPT OF PUBLIC SPEAKING}

Schmitz (2012) said that the dialogue theory of public speaking understands that public speaking is a dialogue between speaker and audience. This dialogue requires the speaker to understand that meaning depends on the speaker's and and hearer's vantage points and that context affects how they must design and deliver their messages.

\section{SPEAKING SITUATION : AUDIENCE, OCCASION, PURPOSE}

When people intend to speak in public, there are some elements they should consider. The element of public speaking listed below (UMC:2007):

\section{Audience}

Speakers communicate differently to different audiences. To take a simple example, people tell their grandmothers about their new - significant other\| in a different way than they tell their best friend. Similarly, people speak about trees differently with their high school biology teacher than they do with their younger siblings; and speakers often need to make arguments about public policy differently to Republicans than to Democrats. Two main questions guide audience adaptation in a speaking situation: Who are they? What qualities about them are relevant? Who are they? Distinguishing general from specific audiences is useful. A general audience is everyone who will hear the speech or read the paper. A specific audience, on the other hand, is that subset of the general audience who the speaker particularly wants to reach, or to reach in a different way than the rest of the group. In an audience with varying degrees of knowledge on a subject, for instance, a speaker might want to pitch their comments primarily to non-experts (while at the same time not saying anything that a specialist would find objectionable). In the classroom, students may be speaking to the entire group but making a special effort to address the professor's expectations. What qualities about them are relevant? Audiences vary in values, knowledge, style of 
communication, and intellectual capacity — among other qualities. Depending on the topic and purpose, effectiveness could be influenced by whether the audience is young or old, rich or poor, female or male, highly religious or less believing, college graduates or high school dropouts, ethnic minorities or majorities. In addition, audiences carry different expectations to a speaking occasion: some want to be there, others do not; some want to be entertained, others are looking to be informed; some are open to being persuaded while others are unlikely to change their minds anytime soon; some expect a highly polished presentation with sophisticated visual aids while others are looking for less formal comments. All of these expectations help shape a speaking situation.

\section{Occasion}

Unlike much written communication, a public speaking situation occurs at a specific time and place. With regard to time, the speech can be affected by events that have very recently occurred (e.g. the morning's news may be fresh in your audience's mind); by the time of day (8:00 A.M. lectures are different than 10:00 A.M. lectures); and by the fact that it comes after or before other speeches. Place matters too--different-sized rooms make a difference for visual aides and intimacy. There is also a reason that the speech is happening, the occasion for which the audience has gathered. Are you speaking at a wedding or a funeral? An academic lecture series or a public meeting of concerned citizens? A mandatory assignment for freshman communication students? Each of these occasions has different norms for speaking, calling for speakers to operate in different modes--from formal to informal, from light to heavy, humorous to serious, conversational to highly practiced.

\section{Purpose}

Speakers hope to accomplish general and specific purposes when they communicate. For most speaking in college and beyond, there are two general purposes: to inform or to persuade. When a speaker seeks to inform, they want the audience to leave the speech knowing more than they knew beforehand. Speakers may want to explain an idea or process, share new information, or show how to do something. When a speaker aims to persuade an audience, they want them to adopt a new position or belief, to change their minds, or to be moved to action. 


\section{Structuring the Speech}

Organizing speeches serves two important functions. First, organization helps improve clarity of thought in a systematic way. Second, organization increases the likelihood that the speech will be effective. Audiences are unlikely to understand disorganized speeches and even less likely to think that disorganized speakers are reliable or credible. Speeches are organized into three main parts: introduction, body, and conclusion. The introduction of the speech establishes the first, crucial contact between the speaker and the audience. For most classroom speeches, the introduction should last less than a minute. The introduction needs to accomplish three things:

Focus on Audience's Attention. Speakers must have an -attention grabber\| to interest the audience - a joke, astonishing fact, or anecdote. (Rhetorical questions like -Haven't you ever wondered how... $\|$ are notoriously ineffective.) The introduction is the place where the main claim or idea should be stated very clearly to give the audience a sense of the purpose of the speech. Speakers need to orient the audience and make connections between what they know or are already interested in and the speech topic.

Establish Goodwill and Credibility. Many people believe the most important part of persuasion was ethos, or the character the speaker exhibited to the audience. The audience needs to see the speaker as someone to listen to attentively and sympathetically. Ethos is generated by both delivery style and content of the speech. Making eye contact with the audience and displaying confidence in voice and body are two important ways to establish ethos. In addition, if you express ideas that are original and intelligent, you will show -intellectual character.ll Audiences pay attention to habits of thought that are interesting and worth listening to.

Give a Preview. Mentioning the main points to be covered in the body prepares the audience to listen for them. Repetition is an important aspect of public speaking, for listening is an imperfect art, and audience members nearly always tune out in parts-sometimes to think about previous parts of the speech, sometimes for other reasons. The preview should end with a transition, a brief phrase or a pause to signal to the audience that the speech is moving out of the introduction and into the body. The body follows and is itself structured by a mode of organization, a logical or culturally 
specific pattern of thinking about ideas, events, objects, and processes. Having a mode of organization means grouping similar material together and linking the component parts together with transitions. Good transitions show the relation between parts of a speech. They display the logic of the speech. Common transition phrases include: in addition to, furthermore, even more, next, after that, then, as a result, beyond that, in contrast, however, and on the other hand. One special type of transition is called the internal summary, a brief restatement of the main point being completed. In the body, the fewer the main points the better. For short classroom speeches, under 10 minutes, speeches should not have more than three main points. For longer speeches, more than five main points ensures that audiences will have trouble following and remembering the speech. In the speech, main points should be clearly stated and "signposted," marked off as distinct and important to the audience. Transitions often serve to signpost new points, as do pauses before an important idea. Additionally, speakers might number main points - first, second, third or first, next, finally. Always make it easy for the audience to recognize and follow key ideas.

There are several common modes of organizing the information in the body of the speech:

\section{Temporal Organization}

Groups information according to when it happened or will happen. Types of temporal patterns include chronological (in the sequence it occurred) and reverse chronological (from ending back to start). Inquiry order is one special mode of temporal organization useful in presenting some kinds of research: here you organize the body in accord with the unfolding processes of thinking and gathering data, taking the audience from the initial curiosity and questions to final results.

\section{Cause-Effect}

Related mode of organization, showing how one event brings about another. Causeeffect, like other temporal modes, may be used for past, present, or future events and processes. Cause-effect can also be reversed, from effect back to cause. 
Spatial Patterns group and organize your speech based on physical arrangement of its parts. If a speech is describing a place, a physical object, or a process of movement-downtown Mercer, a plant cell, or the Battle of Shiloh--spatial patterns can be useful.

Topical Designs are appropriate when the subject matter has clear categories of division. Government in the United States, for instance, falls into federal, state, and local categories; or into executive, legislative, and judicial branches; into elected and appointed officials. Categories like these can help divide the subject matter to organize the main points.

\section{Compare/Contrast}

Takes two or more entities and draws attention to their differences and/or similarities. Sometimes speakers explain a difficult subject by comparing it with an easier, more accessible one--to explain nuclear fusion with the stages of high school romance, for instance. The use of analogies often assists in audience understanding. Following a transition from the body of the speech, the conclusion follows. The conclusion should be somewhat shorter than the introduction and accomplishes two purposes: summarize main ideas and give the speech a sense of closure and completion. Good conclusions might refer back to the introduction, offer an analogy or metaphor that captures the main idea, or leave the audience with a question or a challenge of some type. Brief quotations can also make effective conclusions (just as they can make effective openings for introductions).

\section{RULES OF THREE}

Hughes (2016) said that the power of three is an impactful speech writing technique that public speaker can (and should) indeed learn, practice, and master. Threes are deeply embedded in people's culture as easy ways to remember things. Most people share the feeling that if they have one piece of information, they can probably slot in another piece of information on either side to make three in total. The outline of an effective speech will have three sections: an introduction, body and conclusion. The repetition is powerful because it can make your message more persuasive, memorable, and entertaining. It was no coincidence that these three part quotes are well known: "Life, liberty, and the pursuit of 
happiness; -sex, drugs, \& rock n' roll"; "truth, justice, and the American wayl (Superman's three things worth fighting for. Superman is cool.). It was also no coincidence that good stories have a beginning, middle, and end. Films, literature, and video games are often crafted in the form of a trilogy. Three IS a magic number. Using the Power of Three allows public speakers to convey concepts more thoroughly, highlight your points, and increase the prominence of the message.

The examples of the Power of Three can be found in some of the most famous speeches ever written:

- -Friends, Romans, Countrymen. Lend me your ears. - - Shakespeare's Julius Caesar

- -Government of the people, by the people, for the people - - - Abraham Lincoln's Gettysburg Address

- "Our priorities are Education, Education, Education" - Tony Blair

The rule of three describes triples of all types - any list of three related elements. Two more specific variants are hendiatris and tricolon.

\section{Hendiatris}

A hendiatris is a figure of speech where three consecutive words are used to express one idea.

Examples include:

- “Liberté, Égalité, Fraternité" (French motto)

- “Citius, Altius, Fortius" (Olympic motto)

- "Wine, women, and song $\|$ (Anonymous)

\section{Tricolon}

A tricolon is a series of three parallel elements (words or phrases). A tricolon is a sentence with three clearly defined parts (cola) of equal length, usually independent clauses and of increasing power.

Examples include:

- "Veni, vidi, vici.\| (Julius Caesar) 
- -Be sincere, be brief, be seated.\| (Franklin D. Roosevelt)

- -Never in the history of human endeavor has so much been owed by so many to so few\| (Sir Winston Churchill)

Three is the smallest number of elements you need to create (or break) a pattern. Using the power of three allows you to change your audience in some way: inform them, inspire them, or amuse them. Focusing your message on no more than three significant points, and repeating them in different ways throughout your presentation, is certain to give your presentation the maximum impact. Using The Power of Three is one of the most simple and effective ways to make audience remember public speakers and their words.

\section{THE ASSESSMENT OF PERSUASIVE PUBLIC SPEAKING IN SPEAKING CLASS}

The assessment of public speaking used Competent Speaker Speech Evaluation Form from NCA.

\section{METHODOLOGY}

The method of the study was descriptive. Descriptive method help provide answers to the questions of who, what, when, where, and how associated with a particular research problem; a descriptive study cannot conclusively ascertain answers to why. Descriptive research is used to obtain information concerning the current status of the phenomena and to describe "what exists" with respect to variables or conditions in a situation (Eugene\& Christine, 2015). The subject of the study was the fourth semester studentsThe data was collected by using content-analysis. It consists of analyzing the contents of documentary materials such as books, magazines, newspapers and the contents of all other verbal materials which can be either spoken or printed (Kothari, 2004:110). The object of the study was the fourth semester students of Speaking class of University of Riau Kepulauan. Sample of the study was Class 4A English class.

\section{RESULTS}

\section{Data 1:}

Group I: Theme: —Go Green\| 
Aim: to persuade

Rules of tthree : Anaphora: Go green...go easy..go happy

Effect: : Asked audience to be wise in dealing with their trash by using green way. The message was understandable as the use of rules of three was simple. The audiences were very interesting as it was presented in a great way.

\section{Data 2:}

Group II: Theme: -No Smoking\|

Aim: to persuade

Rules of three : None

Effect: : Too many details but not focus on the important one. The audience was not so interesting as the theme was also too common. However

\section{Data 3:}

Group III: Theme: -LGBT\|

Aim: to persuade

Rules of three : None

Effect: : Too many details but not focus on the important one. The audience was not so interesting as the theme was also too broad.

\section{Data 4:}

Group IV: Theme: - Residence Propertyll

Aim: to persuade

Rules of three : Anaphora: None

Effect: : As none of rules of three used, their public speaking only talked about the residence from the yard and not involve the audience and props.

\section{DISCUSSION}


From all groups of persuasive public speaking presentation, only one of them used one rules of three, Though those groups used colorful pictures or interesting props but the message that wanted to be delivered none. The use of rules of three can make their speech more powerful and simple so the audiences will be understood.

\section{REFERENCES}

Gallo, Camillo. (2014). The magical number that will amplify your next presentation. Entrepeneur Press. Retrieved from: https://www.entrepreneur.com/article/231766.

Hughes, Sarah Llyod. (2016). Power of three. Ginger Public Speaking.

Kothari, C.R.(2004). Research methodology: Method and technique. New Age International (P) Limited, Publishers: New Delhi.

M, Eugene \& Christine E. Lynn. (2015). SOC-200 Research methods in the social sciences: descriptive design. Lynn University. Retrieved from: http://lynnlibrary.libguides.com/researchmethods.

Morreale, Sherwyn et al. (2007). The competent speaker speech evaluation form: Second Edition. Washington, D.C.:National Communication and Association. Retrieved from: https://www.natcom.org/uploadedFiles/Teaching_and_Learning/Assessment_Resources/P DF-Competent_Speaker_Speech_Evaluation_Form_2ndEd.pdf.

Schmitz, Andy. (2012). Public speaking: Practice and ethics. Retrieved from: Creative Common. http://2012books.lardbucket.org/pdfs/public-speaking-practice-and-ethics.pdf

Web Team, UMC. (2007). Public speaking: The basics. University of Pittsburgh. Retrieved from: http://www.speaking.pitt.edu/student/public-speaking/basics.html. 